\title{
Value Added Statement: A Part of Social Responsibility Reporting
}

\author{
Md. Afzal Hossain \\ Department of Business Administration, Shanto-Mariam University of Creative Technology, Uttara, Dhaka, Bangladesh \\ Email address: \\ aafxal_005@yahoo.com \\ To cite this article: \\ Md. Afzal Hossain. Value Added Statement: A Part of Social Responsibility Reporting. Journal of Finance and Accounting. \\ Vol. 5, No. 2, 2017, pp. 74-79. doi: 10.11648/j.jfa.20170502.11
}

Received: January 28, 2017; Accepted: March 2, 2017; Published: March 25, 2017

\begin{abstract}
In this paper I have tried to show how and to what extent, the value added Statement can supplement additional financial information to satisfy all the stateholders of the enterprise. This study sets out to determine whether sufficient evidence on the usefulness of the statement, from the perspective of the users exists. The paper examines some of the theoretical issues regarding the publication of the value added statement as a voluntary disclosure in the process of accounting communication. The social and economic motivation to use value added reporting is linked to the general process of disclosing financial information in a certain business and cultural environment. In this framework, a question arises about the possible role of the value added statement as a way of accounting communi cation in the global economy.
\end{abstract}

Keywords: Value Added Statement, Annual Reports, Voluntary Disclosures

\section{Introduction}

The activities of a company have both economic and social impacts on the users of information. A company is accountable to the society since it makes use of community-owned assets, such as roads, railways, means of communications, harbors, and other infrastructural facilities and concessions provided by the State from the taxpayers' money. A value Added Statement (VAS) is regarded as a part of social responsibility reporting. Under the market economic condition, enterprise is a profit entity, whose goal and motivate is pursuing profit and the biggest economic benefit. While value-added is the natural characteristic of capital, value-added accounting and management services enterprise pursuing the maximum value, value-added and economic benefits. At present, the valueadded accounting and management which is formed by preparing value-addedsheet is popular in Japan and many Europe and America industrialized countries. Here the valueaddedis the remainder that the revenue coming from the operating for some periods deducts the expenditurefor buying merchandise and labor outlay.

\section{Purpose of the Study}

The purpose of this thesis is to examine the limits of traditional accounting and to develop and apply an alternative accounting framework called the Expanded Value Added Statement (EVAS). This framework allows organizations to estimate their economic, social and environmental value added. I locate the Expanded Value Added Statement in accounting theory, and particularly reformist accounting theory. I intend to demonstrate that the Expanded Value Added Statement can be effectively applied to nonprofit, forprofit and public-sector organizations to signal an organization's commitment. The present study highlights the theoretical framework of the concept of value added and the Value Added Statement, and the usefulness of such VAS as a supplementary financial statement, in addition to traditional financial statement, which can satisfy the additional information needs of all the stakeholders of business, as a part of social responsibility reporting to sustainability, defined here as improving quality of life and reducing environmental degradation.

\section{Methodology}

The study is exclusively a descriptive research and thus it is purely based on the information from secondary data sources. The data collected for the purpose of the study involve the examination of annual reports of listed companies, documents, 
magazines, books, journals, various newspapers, and subject related websites and research documents. The study concentrated on the critical analysis of data available from the financial statement. Data are compiled after considering necessary re-arrangement for the purpose of the study.

\section{Review of Literature}

The concept of value added income is not new one. This concept was first introduce in the computation of national income, which is usually considered as the production of goods and services during a time span within a national boundary [1]. The concept has been introduced in the corporate reporting during seventies and has been gaining popularity since the publication of "The Corporate Report" by the Accounting Standard Steering Committee (ASSC), London in 1975 and "The Future of Company Reports". A comprehensive document of British Government, published by HMSO, in London in July 1977. ASSC has recommended various expansions to financial reporting in order to improve and enhance both the understandability and reliability of traditional financial statements and techniques. As a result supplementary financial statements have been developed and the companies are advice to prepare statement like Value Added Statement(VAS), statement of proprietary Fund, etc in addition to profit and loss Statement and Balance sheet. In a long and consistent history of its use, value -added income has been used in the area of public finance with a view to imposition of taxes. A review of the publication of the VAS around the world has indicated that a significant number of companies in the Netherlands, France, and Germany have provided value added data. There have also been growing instance of VAS being disclose in countries such as Denmark, Switzerland and Italy. In U.K., after the publication of "The Corporate Report" in 1975, many large companies are incorporating value added statement in their annual Reports. In May 1976 the Department of Trade issued a preliminary draft paper "Aims and Scope of Company Reports" recommending, amongst other thing, the company reports should be include a statement of value added. Then in July 1977 Green paper has been published on "The Future of Company" Reports" which supported many of the ideas put forward in the documents, including added value statement. Value Added Reporting(VAR) even though not always mandated, is being increasingly popular in Europe, Australia and Singapore. In Australia there is no statuary obligation on the part of companies to present VAS in their Annual Reports. However, Australia corporate disclosure have indicated that majority (63\%) of the companies have adopted a disclosure practice of VAS. In U. S. A, although US companies have not included value added information in their annual reports, many authors strongly feel that it must be made available to the users.[4] [10]. In South Africa the interest in value added started with the publication of the "The Corporate Report", in 1975. This led to six companies in top 100 publishing VAS in 1977. Unlike other countries where the publication of VAS has reduced, in South Africa, companies publishing the value added statement has increased, with a total of 74 companies in the top 100 producing VAS in 1990. In 1997, more than 200 companies listed in the industrial sector of Johannesburg Stock Exchange (JSE) have published VAS voluntary as part of their annual financial statement [16]. This is the highest incidence of publication of VAS reported in the world to date, which makes South Africa the best place to investigate the publication of the VAS. In India VAS is a voluntary corporate financial supplementary statement, which provides the information regarding the financial performance of a corporate entity in such a fashion as would be easily be understood by layman to expert. [9]. A very few progressive companies in India like SAIL, MNTC, BPCL,BHEL,CCI etc. in public sector and Indian Rayon, Infosys Technologies Ltd. Britannia Industries Ltd, Escort Ltd, Global Telesystem Ltd. Etc. in private sector, are producing value added statements in their annual financial reports. However, at the macro level, the first recorded use of value added was n 1970 when TRENCHCOX used it in the first US Census Production.

\section{Historical Perspective}

\subsection{Macro Level}

The concept of value added has long been utilized in measuring national income. The Net National Product(NNP) is value added on available national resources during the measurement period. Value added was used in 1970 in the first US Census of Production.

\subsection{Micro Level}

At the micro level, however, the use of value added is recent. In Germany, the value added statement is required, by law, to be prepared by all manufacturing companies since 1965. In the UK, as a result of the many large companies are included value added statements in their annual reports. In the late seventies, around 20 percent of the large UK companies to be the main focus. "The shareholders" interest should take precedence over relationships with employees, customers and other corporate constituencies. [8] [14]

\subsection{Meaning and Significance of Value Added Statement}

A business enterprise specifically a company is a conscious, deliberate and purposeful creation for satisfying the domain of aspiration of the society at large. It is an independent and separate legal entity. The survival stability and growth of such entity within the society largely depend on the wealth created by it through the collective efforts of all the stakeholdershareholders, providers of loan capital, employees and the government. All these stakeholders are the parties to whom the result of operations of business is communicated. To satisfy the information needs of these users, the conventional financial accounting system generate data relating to financial performance through profit and loss Statement or Income Statement giving emphasis on the interest of shareholders(i.e. owners) only. The Profit and loss Statement does not provide 
any information showing the extent of the value or the wealth created by the company for a particular period. Contribution to the company by other stakeholders cannot be accessed through the Profit and Loss Statement. Hence, there is a need to modify the existing accounting and financial reporting system so that a business unit is able to give importance to judge its performance by indicating the value or wealth created by it. To this direction inclusion of the value added statement (VAS) in financial reporting system is a newly developed technique, which is regarded as a part of social responsibility accounting and reporting. [7]

A Value added statement shows the value (wealth) created and attributable to all stakeholders' rather than just the shareholders. The value added statement is now being regarded as a preferable way of describing performance. Profit is only a part of value added. Wages, dividend and interest, taxes and funds for new investment all form components of the value added. [18]

"While the income statement reports on the income of shareholders, the value added statement report on the income earned by a larger group of stakeholders-all providers of capital plus employees and the government. [14]

The VAS, supplements, rather than supplants, the income statement. As a supplementary statement, the VAS provides information to the shareholders and other groups in a manner that may be more meaningful to them.

\subsection{Uses of Value Added Statement}

The Corporate Report (ASSC) says that there is evidence that the meaning and significance of profit are widely misunderstood, and in the time to come, value added may be regarded as a preference. Profit-based reporting is likely to be more subjective. On the other hand product based repots are more objective. Profits measure only the shareholders' share of a company's result of activities. Value added puts profit in a different perspective. [5]

Morley argues that employees that employee have an interest in the wealth created by their company during the year, the share they received in the form of pay, as well as the proportion reinvested to strengthen the company and enhance future job security. The income statement, apart from being more complex than a value added statement, is not of particular relevance to the employees [6]

The Chairman of Avon Products (U.S.A) argued that "executives have duties beyond maximizing value for shareholders. We have 40,000 employees, 1.3 million representatives around the world. We have a number of suppliers, institutions customers and communities..... They have much deeper and much more important stakes in our company than our shareholders. [12][13]

\subsection{Assumption in VAS}

Following assumption are made to derive the value added income through the preparation of Value Added Statement (VAS):

i) VAS is not a substitute but a supplement to the Profit and Loss Account.

ii) It is prepared on the basis of data recorded and processed by the conventional accounting system.

iii) In the preparation of VAS the accounting concept and principles of accounting are remaining the same.

\subsection{Objective of $V A S$}

The main objectives of preparing VAS are as follows:

i) To disclose the value added by a firm during a period of time.

ii) To indicate the wealth created by an enterprise for the purpose of evaluating and measuring the performance of the business unit.

iii) To study the pattern of distribution of value added to all the stakeholders-employees, providers of loan capital, governments and owners.

iv) To use it as the basis for making inter-firm and intrafirm analysis, for preparing plans and fixing targets, for developing productivity incentive schemes and for leading to an improvement in team spirit, etc.

v) To collecting revenue by way of levying tax on value added instead of on net profit.

\subsection{Classification and Computation}

Value Added may be classified into two categories:

a) Gross Value Added(GVA) which refers to sales plus income from other services less bought in materials and services purchased from outsider; and

b) Net Value Added (NVA), which refers to the difference between GVA and Depreciation. In other words, NVA is the sum of the value added to employees, to providers of loan capital, to Government and to owners

Bernard Cox suggested the following two methods two methods for computing Gross Value Added (GVA):

i) Additive approach: Under this approach gross value added is computed by using the following equation:

$$
\mathrm{GVA}=\mathrm{PBT}+\mathrm{EC}+\mathrm{D}+\mathrm{I}
$$

Where, $\mathrm{PBT}=$ Profit Before Taxes, $\mathrm{D}=$ Depreciation $\mathrm{EC}=$ Employee Cost and I=Interest

ii) Subtractive approach: Under this method Gross Value Added (GVA) is calculated by using the following equation:

$$
\mathrm{GVA}=\mathrm{S}+\mathrm{IS}-\mathrm{CBGS}
$$

Where, $\mathrm{S}=$ sales

IS $=$ Income from services

CBGS $=$ Cost of Brought in goods and services. [3]

Studneskipaul suggested following two methods for calculating Net Value Added

i) Income Distribution Method: In this method Net Value added(NVA) is determined by the following equation:

$$
\mathrm{NVA}=\mathrm{VAW}+\mathrm{VAG}+\mathrm{VAF}+\mathrm{VAE}
$$

Where, VAW=value added to worker/ employees, 
$\mathrm{VAG}=$ Value Added to Government,

$\mathrm{VAF}=$ value added to Financer, $\mathrm{VAE}=$ Value Added to Equity.

ii) Net output method: under this method Net Value Added is determined by the following equation:

$$
\mathrm{NVA}=\mathrm{GVA}-\mathrm{D}=(\mathrm{S}+\mathrm{IS})-\mathrm{CBGS}-\mathrm{D}
$$

Where, $\mathrm{S}=$ sales, $\mathrm{IS}=$ Income from services, $\mathrm{CBGS}=$ Cost of Brought in goods and services, $\mathrm{D}=$ Depreciation

Accounting Standard Steering Committee (ASSC) suggests a formula for computing Value Added (VA), which as follows:

$$
\mathrm{VA}=\mathrm{a}-\mathrm{b}=\mathrm{c}+\mathrm{d}+\mathrm{e}+\mathrm{f}
$$

Where, $\mathrm{VA}=$ Value Added, $\mathrm{a}=$ Turnover, $\mathrm{b}=$ Bought in materials and services, $\mathrm{C}=$ employees wages and other benefits, $d=$ Dividend and Interest payable, $\mathrm{e}=$ Tax payable and $\mathrm{f}=$ Retained profit.

\subsection{Measurement of Value Added}

The value added of a firm during a specific period of time may be stated as:

Value Added = Value of Output minus Value of Inputs Purchased from other firms(also termed as 'throughputs'.)

Basically, two factors are to be determined for computing the value added:

i) Value of output

ii) Cost of 'throughputs'. (Throughputs includes all itemsmaterials and services-purchased from other firms.)

\section{Conceptual Issues in VAS Preparation}

Various studies on the treatment on the computation of value added have found that the practices have been diverse. A great deal of discretion exists as to the treatment of depreciation, taxation and styles of format to be used with the different captions of value added. Let us discuss some of these diverse practices because they have bearing on the conceptual aspects of value added.

\subsection{Depreciation}

There are two way of treating depreciation: The first approach results in gross value added, and second results in net value added.

(i) Gross Value Added: This approach has been recommended by the Corporate Report(ASSC, London). In this approach, the value added by a firm is not reduced by the depreciation charge. Depreciation is shown as an item reinvested in business. It is treated as an application for the maintenance and expansion of business, and shown as retained earnings. According to a survey in the U.K., $80 \%$ of the company disclosing the value added statement, calculate value added of depreciation. [2]

(ii) Net Value Added: In this approach, the depreciation charge is included in the value of bought-in materials and services. The rationale of this approach is that like other 'throughputs', depreciation should be deducted from the value of the output since diminution in the value of fixed assets used in creating new value is also a part of these costs. Fixed assets, whose costs are depreciate, are purchased from outside the stakeholder group, like materials and services.

\subsection{Indirect Taxes}

Some of the different kinds of indirect taxes are sales tax and excise duties, rates, road fund tax, petroleum revenue tax. Should these taxes and duties be shown as the Government's share or should these be taken into account while calculating the value added. The general opinion is that only corporate tax, less subsidies if any, should be shown in the share of the government, while the sales and excise duties paid on material and services purchase from outside can be considered as a part of these materials and services. Similarly, the sales and excise duties collected on the products sold may be excluded from the sales taxes revenue, and thus from value added. This treatment is consistent with the idea that the Government has played no role in the wealth created by the firm in the private sector. The treatment can however be different for the government or public sector.

\subsection{Pay-As-You-Earn (PAYE) and National Insurance Contribution}

The consensus is that these items should be included in the employees' share.

\section{4. $V A T$}

Sales revenue should be shown net of VAT so that it is not included in the value added.

\subsection{Other Items}

The question arises whether or not extraordinary, nonoperating and translation gain/losses represent value added. Strictly speaking, they do not arise from normal production activities, but they do affect the overall income of the firm. There is a wide variation in practice even in U. K. based companies. The only point in favour of including these item is that they provide a basis for the reconciliation with the profit and loss statement. Theoretically however, these items arise from activities other than normal operating activities, and hence they should not be included in value added.

\subsection{Inflation and VAS}

In the VAS, sales revenue is shown at current value, and this is juxtapose with bought in material and services at the cost of acquisition. There is no matching of expense with associated revenues earned during the period. This can be possible only when the throughputs are shown at replacement cost (or any other current value).

\subsection{VAS on Cash Flow Basis}

It is recognized that the cash flows provide a better 
measurement of liquidity. Careful thought needs to be given to the preparation of VAS on cash flow basis. This will avoid the highly subjective item of depreciation charge.

\section{Need for Standardization in Reporting Value Added}

The entire purpose of comparability will be vitiated if reporting practices are diverse. The above discussion clearly highlights the need for consistency and uniformity in value added statements. The professional body (or the Government) should issue guideline for the preparation and presentation of such statements. Only then will the value added statements serve a useful purpose. The VAS may be required to be issued as a supplementary statement.

\section{Format of VAS}

The Value Added Statement(VAS) is usually divided into two parts: (A) Generation of Value Added and (B)Application of Value Added. It can be prepared in "Report or Vertical Form. The Form is shown below:

XYZ Company

Value Added Statement(Report or Vertical Form)

For the year ended $31^{\text {st }}$ December

Table 1. Value Added Statement formet.

\begin{tabular}{ll}
\hline Particulars & Amount (TK.) \\
\hline $\begin{array}{l}\text { Generation of Value Added: } \\
\text { Sales/Turnover(Including excise duties and sales tax } \\
\text { excluding Returns, rebates and discounts etc.) } \\
\pm \text { Stock of semi-finished goods }\end{array}$ & \\
& $* * *$ \\
Production value & $* * *$ \\
Add: Income from services & $* * *$ \\
& $* * *$ \\
Less: Bought-in-goods and services purchased from & $* * *$ \\
outsiders & $* * *$ \\
Gross Value Added(GVA) & $* * *$ \\
Less: Depreciation and deferred Revenue expenses & $* * *$ \\
Net Value Added(NVA) & $* * *$ \\
Application of Value Added: & \\
Receipt by Workers/ Employees & \\
Receipt by Providers of Loan Capital & $* * *$ \\
Receipt by Government & $* * *$ \\
Receipt by Owners & $* * *$ \\
Net Value Added(NVA) & $* * *$ \\
\hline
\end{tabular}

\section{Findings of the Study}

The following are the most important implication of the study:

i. The performance analysis of the company on the basis of Value Added figure reveals the distributive judgment in respect of all the participants of the company. This is not possible through the performance analysis on the basis of Net Profit figure only. ii. VAS of the company provides the means to satisfy all the stakeholders and as a result, the analysis creates feelings in the mind of all the participants that the company is able to create wealth for the society at large, leading ultimately to a strong basis favoring social approval to carry on its business activates.

iii. For easy growth and expansion of a business enterprise the analysis of VAS suggests some important guidelines for framing the retention and dividend policy of the enterprise.

iv. The analysis also gives us an impression about the future contribution by the business unit towards different stakeholders of the company and also targeted profit of the company in future.

\section{Conclusion}

In a word, at present in our country, enterprise building value-added accounting and executing value-added management is a bridge of linking macro accounting with micro accounting. It is benefit for combing accounting with management; compensating for the shortcomings of present accounting and enterprise management system. At the same time, it can affect enterprise's value-added strategy, plan and budget deeply; transfer enterprise's financial goal from traditional short-term profit goal to long-term value-added one. With the new development of accounting, especially the present accounting expanding to inflation accounting, we can solve much of the pricing difficulties of the first kind of value-added accounting and management, and provide good condition for it executing. On the other hand, with maturation and standardization of our security market, building and perfecting of modern enterprise's system, EVA economic value-add accounting and management will make great effect to our economy and management.

\section{References}

[1] B. Cox, 1979. Value Added- An Appreciation for the Accountants concerned with Industry, Institute of Cost and Management Accountants, 1978, quoted in Michael F. Morely in 'The Value Added Statement in Britain, The Accounting Review Vol. LIV, No. 3 July, p-620.

[2] Bougen, P. D., Value Added in Tonkin, D. J. and Skerrat, L. C., Financial Reporting 1983-84: A survey of U. K. published Accounts, ICAEW, 1983, p. 156.

[3] Bernard, cox, Added Value and Corporate Reporting, Management Accounting, April 1976, pp 142-146).

[4] Cruns R. P. 1982. Added-Value: The Roots Run Deep into colonial and Early America, Accounting Historian Journal (Fall 1982) pp 25-42.

[5] K. Natrajan, Journal of Accounting and Finance, Fall 1991.

[6] Moreley, M. F., Value Added: The Fashionable Choice for annual Reports and Incentive Scheme, The Accountant's Magazine, June 1979, p 235. 
[7] Mondol, Goswami, Value added Statement (VAS) -A critical Analysis-A case study of Bharat Heavy Electricals Limited, Great Lakes Herald, Vol. 2 No. 2, September 2008.

[8] Pickens, T. B. jr. professions of a Short-Termer, Harvard Business Review, May-June 1986, p. 78.

[9] Rao, P. M. 2000. "Value Added Reporting: in Theory, Practice and Research", Deep and Deep Publications Pvt. Ltd., New Delhi, pp 49-50.

[10] RiahiBelkaoui A, 1992. Value Added Reporting -lessons for the United States, Quorum Books, Westport, Connecticut.

[11] RiahiBelkaoui, A, 1996. Performance Results in Value Added Reporting, Quorum Books, Westport, Connecticut.
[12] The Battle for Corporate Control, International Business Week, May 18, 1987, p 71.

[13] The U.S. Must Meet the Challenge, International Business Week, April 20, 1987, p. 184.

[14] The Corporate Report, ASSC, 1975, London, p. 49.

[15] The Future of Company Report, 1977. Green paper published by HMSO: London: A Consultative Document of British Government, p-15.

[16] Van Staden C. J., 2000. Revisiting the Value Added Statement: To published or Not to publish; In proceedings of the $12^{\text {th }}$ Asian Pacific conference on International Accounting issues, October 21-24, page 20-23. 